\title{
Study on the Characteristics of Genealogy Contract Documents in Qing Dynasty
}

\author{
Fengfan $\mathbf{L i}^{1}$, Junjie $\mathbf{L i}^{2}$ \\ ${ }^{1}$ School of International Education, North China University of Water, Resources and Electric Power Zhengzhou, Henan, 450045 \\ ${ }^{2}$ School of Marxism, Zhoukou Normal University, Zhoukou, Henan, 466001
}

\begin{abstract}
According to the data collected from the genealogical contract documents from the Qing Dynasty to 1949, the genealogical contract documents were first published in the Shunzhi period of the Qing Dynasty, and the contract documents clearly stated that the genealogical contract documents should be published in the Qianlong period. However, the surviving amount of genealogical deed documents is less than one thousandth of the existing genealogy. It is estimated that the surviving amount of genealogical deed documents is less than 5000. As for the type of genealogical contract document, it is roughly the same as the type of scattered contract document, mainly land sale contract document, and genealogical contract document is related to the interests of the clan. The main purpose of the contract in the genealogy is to protect the interests of the family property from loss, so as to maintain the permanent existence of the family property.
\end{abstract}

Keywords: From the Qing Dynasty to 1949, The deed in the genealogy, Characteristics.

\section{Introduction}

"The contract document is a kind of private document which has been widely used for thousands of years in China. All kinds of real rights and creditor's rights in social life need to be affirmed in the form of documents to show good faith and guarantee the performance of the rights and obligations of the parties, and then the contract documents are formed. Therefore, it is a kind of legal documents and private files, but also a specific period and a specific area of social economic relations of private law norms."'[1] Contract documents can be divided into scattered contract documents and document contract documents according to different storage carriers. Document contract documents can be divided into genealogy contract documents, tablet inscription contract documents according to different specific carriers. And of course a genealogical deed is the deed that puts the deed into the genealogy. This paper mainly expounds the genealogical contract documents compared with the scattered contract documents. A single contract document and a genealogy contract document are basically the same in the subject, content, and end of the contract. The key is that the two are not completely the same in content.

\section{Characteristics}

\subsection{The Time When the Contract was Entered into the Genealogy}

According to the collected genealogical contract documents in the Qing Dynasty, the earliest contract document published in the genealogy was a contract of maintenance agreement on the family tree of the Xie clan in Shangcheng, Henan during the Shunzhi Emperor period of the Qing Dynasty. What is the general meaning of the contract: The contractor, Deng Yingluan, was born to a daughter due to his old age and no children. With matchmakers Zhu Qiyun and Liu Congsheng, he became married to Xie Jiasheng. The daughter and son-in-law have not yet been married. Unfortunately, I was ill and stayed in bed for a long time. In consideration of the funeral, only the adopted son Deng Quan was stupid, and the clan had no other nephews, and the young girl had no dowry to dowry. At present, he explained to relatives and friends that the son-in-law Xie Pengxiang was recruited. If I recover from illness, I will have a son-in-law to provide for the elderly. And if I die unfortunately, I will take care of my life with my wife. My property will be handed over to my son-in-law and father Xie Jiasheng to manage the family business (because the son-in-law is young). Deed as proof.

witness

Pi Jinchuan, Deng Kui Suo, Jiang Fuyun, Zou Wen Suo, Wu Jiati, his mother-in-law Zhao Defu, Ren Jianlong, Zhao Da, Wu Xiyu.

Shunzhi Emperor sixteenth year October 22nd, autographed[2].

The earliest recorded genealogy was Xiang's Genealogy of Taihe County in Anhui Province, which was compiled during the Jiaqing Period of the Qing Dynasty. There was an earlier genealogy contract document dated from the 28th year of Qianlong Emperor, which was among the known materials and clearly wrote the words "the attached genealogy is always the basis"[3].

The contractor Xiang Sixiang, Qi Yi, Wei Xun, etc., will take a cemetery up to the top of the mountain, five feet and five feet below, and two feet and five feet in width. The voucher will sell it to Xiang Wencai, Wenxiu, etc., and receive it on the same day. The price of the land is a string of two hundred literals, and the money is personally taken, a lot of money. After the self-selling, there is no difference between them, and there is no proof for fear of the aftermath, and the deed of permanent sale of the cemetery is established, and the sons and grandchildren of Jun Jun will be paid with a piece of paper, and the appendix will always be the basis.

witness 
Wang Shengli, Jia Shisheng, Jiang Rushan.

On August 21st, the twenty-eighth year of Qianlong, the pen was written

\subsection{The Surviving Amount of Genealogical Contract Documents}

At present, according to the discovered genealogical contract documents, different number of genealogical contract documents have been found in North, Central, East, Southwest and other regions of China. But in southern Henan, Anhui genealogy contract document number, only the Shangcheng county in the south of Henan Province, has collected 300 or so of the contract documents, especially the Henan Province experienced many times in the history of the war, for the study of some parts of China rural masses to real economic and social life at that time, provides a real historical data, has important historical value, it is estimated that Less than one thousandth of the existing genealogy are included in the contract documents, and the number of existing Chinese genealogy contract documents is less than 5,000. At present, the author has collected about 300 contract documents in Henan Province, and many contract documents in Anhui, Zhejiang, Shandong, Hebei, etc., which have laid the foundation for the study of genealogical contract documents.

\subsection{Types of Genealogy Contract Documents}

The scope of traditional contract documents is extremely wide and the content is very rich. It mainly includes real estate leases and purchases such as land, real estate, forests, venues, and various movable property transactions, as well as loans, mortgages, partnerships, divisions, heirs, inheritance, worship, etc. Litigation and other related activities have formed a wide variety of contract documents. Among them, the field contract, especially the land sale contract has the largest number and the situation is the most complicated[4].

Genealogical contract documents are roughly the same as scattered contract documents in type, and even more abundant than scattered contract documents in type. For example, genealogical contract documents have some mountain sealing contracts signed for the common interests of the clan. However, the genealogy contract documents are mainly land sale contract documents, of which land sale contract documents account for more than $90 \%$, and there are also custody agreement, reconciliation agreement, donation agreement, etc.

\subsection{Reasons for the Inclusion of the Contract in the Genealogy}

Some of the deeds, they're explicitly written in the genealogy; In addition, there are some deed documents, although they are not explicitly listed in the genealogy, but they are still listed in the genealogy. The purpose of both is the same, which is to maintain the loss of property of the family and its descendants, and to maintain the sustainable inheritance of the family property.
The contract documents of Feng's genealogy in Zheshan of Zhejiang Province in Guangxu of Qing Dynasty. Since the founding of our ancestral temple, there have been few donations. Every time there is a problem of being in a position to sacrifice, and after the founding of Meigong, the descendants of Xianxiao have successively donated money or land to make ends meet, or donated land to make ends meet. Over the years, the deed of donation has been handed over to the ancestral temple for collection, and transferred to Bafang for legislation. I'm afraid that the world will be lost or unexpected. If there is any danger, why should I practice in the temple! Therefore, the clan held a public meeting to specify the location of Zhongtian in the ancestral temple, and to print the deed of donation in the genealogy according to the form, so that the descendants can not only have a clear view, but also have no omission, so that they will suffer. Since then, they will not eat for mianxue for thousands of years! Perfect and perfect.

This contract document clearly sets out the reasons for writing into the genealogy.

Now, let's say that there are two types of contracts.

First, contract documents clearly written genealogy, which accounted for under $5 \%$ of the genealogy of contract documents.

For example: In 1937, Huang's genealogy in Shangcheng County of Henan Province recorded the "closed mountain contract". Among them, it was clearly written: "I'm afraid I can't rely on it. I'll set up this agreement to seal the mountain. I'll write it into my genealogy and keep it forever."

The second is not write the word "tree", and in the family tree, of family tree is the most important part of the contract documents. Case mainly is conducive to the interests of the native contract documents, including native buy his surname is the property of the people, mainly is the land; And members of the native property merge with this family and so on, in a nutshell, is native to the contract. So, genealogy contract documents are for native to the contract, namely "self-interest" contract.

\section{References}

[1] Yang Guozhen. Study on Documents of Land Leases in Ming and Qing Dynasties (Revised Edition). Research on Documents of Land Leases in Ming and Qing Dynasties (Revised Edition), Beijing: China Renmin University Press, June 2009 (1st Edition), Preface 1.

[2] Xie Lianke. Genealogy of the Xie Family, 33rd year of Guangxu Empror, Qing Dynasty, Shgangcheng Henan. wood type.

[3] Xiang Guomo. Surname Xiang Genealogy. Taihe County, Anhui. 1934. 